\title{
Chemical and Physical Characteristics of Blended Cements Produced from Softwood Ash
}

\author{
${ }^{1}$ Orogbade B. O. and ${ }^{2}$ Raheem A. A. \\ ${ }^{1,2}$ Department of Civil Engineering, Ladoke Akintola University of Technology, Ogbomoso, Nigeria \\ orogbadeblessing2412@gmail.com (corresponding author), aaraheem@lautech.edu.ng,
}

\begin{abstract}
In an attempt to convert agricultural residue to alternative binding material for use in construction industry, this research considered the use of wood ash from Anacardium- occidentale (kaju) wood which is softwood as a pozzolan in cement production. In this study, the chemical composition (silica $\left(\mathrm{SiO}_{2}\right)$, aluminum oxide $\left(\mathrm{Al}_{2} \mathrm{O}_{3}\right)$, ferric oxide $\left(\mathrm{Fe}_{2} \mathrm{O}_{3}\right)$, calcium oxide $(\mathrm{CaO})$, magnesium oxide $(\mathrm{MgO})$, sulphur trioxide $\left(\mathrm{SO}_{3}\right)$, sodium oxide $\left(\mathrm{Na}_{2} \mathrm{O}\right)$ and potassium $\mathrm{Oxide}\left(\mathrm{K}_{2} \mathrm{O}\right)$ ) of the ashes and the clinker was investigated. The production of blended cements were carried out in the factory by replacing $5-50 \%$ by weight of Ordinary Portland Cement Clinker with the ashes during the manufacturing process. The cement without wood ash serves as the control. The physical characteristic (fineness, initial and final setting times, heat of hydration and residue on $45 \mu m$ sieve), and the chemical composition of the blended cements were also investigated. The results showed that Anacardiumoccidentale ash (AOA) was a suitable material for use as pozzolan since it satisfied the requirement for such a material by having a combined $\mathrm{SiO}_{y} \mathrm{Fe}_{2} \mathrm{O}_{3}$ and $\mathrm{Al}_{2} \mathrm{O}_{3}$ of more than $70 \%$ according to ASTM C 618. The AOA blended cements satisfied standard requirements for up to $20 \%$ replacement level. It was concluded that the wood ash was suitable for use in the production ofblended cements.
\end{abstract}

Keywords: Anacardium-occidentale ash(AOA), Wood Ash (WA), Pozzolan and Blended cement.

\section{Introduction}

Other ingredients in concrete apart from cement which is the only factory made standard component are water and aggregates which are natural materials. Cement is a finely ground, non-metallic, inorganic powder which when mixed with water forms a paste that sets and hardens. This hydraulic hardening is primarily due to the formation of calcium silicate hydrates as a result of the reaction between mixing water and the constituents of the cement (Cement Association of Canada, 2001). Cement is a powdery material made of clinker, gypsum and other additives. It is mainly used to form concrete which is widely used for civil engineering constructions. Cement production is expected to increase from 3.27 billion metric tons in 2010 to 4.83 billion metric tons by the 2030. This increasing demand for cement is expected to be met by partial cement replacement (Coutinho, 2003). The search for alternative binder or cement replacement materials led to the discovery of the potentials of using agricultural residue as cementitious materials.

Agricultural residue use in cement production is an environmental friendly way of disposing large quantities of materials that would otherwise pollute land, water and air. Some agricultural residues which possess pozzolanic properties and have been studied for use in blended cement are Rice Husk Ash (Chungsangunsit et al.., 2007, Coutinho, 2003), Bamboo Leaf Ash (Dwiveldi et al.., 2006), Palm Fruit Ash (Olonode, 2010), Locust Bean Pod Ash (Adama and Jimoh, 2011), Cement Cassava Peel Ash (Salau et al., 2012), Corn Husk Ash (Raheem et al., 2012), Corn Cob Ash (Adesanya and Raheem, 2009, 2010) and wood ash (Raheem and Adenuga 2013, Abdullahi, 2006 and Etiegni and Campbell,1991).

Wood ash could be used as a pozzolan in concrete and mortar (Abdullahi, 2006) since it is obtained from the combustion of wood. It can also be related to fly ash since fly ash is obtained from coal, which is a fossilized wood. Significant quantities of wood ash are currently being produced near the industries that use wood as a fuel partially or fully and this poses a threat to the environment. The possibility of adding wood ash to cement for concrete production was explored by Abdullahi (2006), in which wood ash was used as an admixture in the study. Marthong (2012) analysed the hydration characteristics of saw dust ash admixture cement and concluded that $10 \%$ addition of wood ash to cement is optimum. High calcium wood ash and densified silica fume blended cement paste was characterized by CheahChee and Mahudin (2011). Chemical analysis of wood ash showed that it has pozzolanic properties (Etiegni and Campbell, 1991). Raheem and Adenuga (2013) studied wood ash from bread bakery as partial replacement for cement in concrete and concluded that a maximum of $10 \%$ wood ash substitution is adequate for use in structural concrete. Raheem and Orogbade (2018) studied the characteristics of blended cements produced from hardwood ash and concluded that up to $20 \%$ replacement level of all the wood ashes were suitable for use in the production of blended cements. 
Previous studies showed that many researchers such as Raheem and Adenuga (2013) have worked on the mixture of wood ash and ordinary Portland cement at the point of need, without considering the type of wood (either from softwood or hardwood) and without considering blending of wood ash with clinker and gypsum during factory production of the cement except for Raheem and Orogbade (2018) who studied some hardwood only. Therefore, this study focused on determination of chemical composition of wood ashes from softwood, as well as the physical and chemical properties of the blended cements produced at varying percentage replacement of each wood ash during the manufacturing process.

\section{Materials and methods}

\section{Materials}

The softwood that was used to produce the wood ash is Anacardium-occidentale (kaju), the wood was burnt in a bread bakery that uses wood as fuel for their operation and the ash was collected using clean sacks. The wood ash was sieved and only those retained on a $0.425 \mu \mathrm{m}$ sieve was used for the study. The ash was taken to Larfarge Cement, West Africa Portland Cement Company (WAPCO) Sagamu, Ogun State, Nigeria, for chemical analysis. The analyses of the ash was carried out using X-ray Fluorescence analyser (Model QX 1279). The clinker used to produce the blended cement was obtained from Larfarge Cement, WAPCO Sagamu, Ogun State, Nigeria, which is the clinker used by the company to produce Ordinary Portland Cement (OPC) and the chemical analysis was also carried out.

\section{Cement mixtures}

The milling involved the replacement of $5 \%, 10 \%, 15 \%, 20 \%, 25 \%, 30 \%, 35 \%, 40 \%, 45 \%$ and $50 \%$ by weight of Ordinary Portland Cement Clinker with the ash during the manufacturing process. Ten (10) series of Anacardiumoccidentale ash (AOA), were prepared for cement milling. Ordinary Portland Cement (OPC) without ash content served as the control. As it is the practice in WAPCOSagamu works, $5 \%$ gypsum was used for the cement milling. The milling machine used is a Laboratory Ball Mill (Model R. PM 1400/50, Serial Number 93021.A). The mill was charged with media balls following the order and distribution given below:

$\begin{array}{lll}90 \mathrm{~mm} & - & 8.2 \mathrm{~kg} \\ 80 \mathrm{~mm} & - & 10.0 \mathrm{~kg} \\ 60 \mathrm{~mm} & - & 10.0 \mathrm{~kg} \\ 50 \mathrm{~mm} & - & 4.0 \mathrm{~kg} \\ 30-40 \mathrm{~mm} & - & 12.8 \mathrm{~kg}\end{array}$

The ball mill was charged with the required weight of clinker, AOA and gypsum. After which it was firmly tightened and put in operation for 55 minutes. The specific surface area (SSA) of the cement midstream is tested to ensure that it is not less than $250 \mathrm{~mm}^{2} / \mathrm{kg}$ in line with NIS 439:2000 requirement. The milling was done in batches of $4 \mathrm{~kg}$. Table 1 shows the mix proportion for each batch and the percentage ash replacement.

Table 1: Mix proportion for changing ball mill

\begin{tabular}{|c|c|c|c|c|}
\hline $\begin{array}{l}\text { Percentage of Ash } \\
\text { replacement } \\
(\%)\end{array}$ & $\begin{array}{c}\text { Percentage of } \\
\text { Clinker } \\
(\%)\end{array}$ & $\begin{array}{l}\text { Weight of } \\
\text { Clinker } \\
\text { (g) }\end{array}$ & $\begin{array}{l}\text { Weight of } \\
\text { Ash } \\
\text { (g) }\end{array}$ & $\begin{array}{l}\text { Weight of } \\
\text { Gypsum } \\
\text { (g) }\end{array}$ \\
\hline 0 & 95 & 3800 & - & 200 \\
\hline 5 & 90 & 3600 & 200 & 200 \\
\hline 10 & 85 & 3400 & 400 & 200 \\
\hline 15 & 80 & 3200 & 600 & 200 \\
\hline 20 & 75 & 3000 & 800 & 200 \\
\hline 25 & 70 & 2800 & 1000 & 200 \\
\hline 30 & 65 & 2600 & 1200 & 200 \\
\hline 35 & 60 & 2400 & 1400 & 200 \\
\hline 40 & 55 & 2200 & 1600 & 200 \\
\hline 45 & 50 & 2000 & 1800 & 200 \\
\hline 50 & 45 & 1800 & 2000 & 200 \\
\hline
\end{tabular}


Note:

(i) Gypsum is $5 \%$ of the total weight throughout.

(ii) Total weight charged per batch was $4000 \mathrm{~g}$.

\section{Testing of blended cements}

The following physical characteristics of each of the softwood blended cements produced were determined:-

Fineness: - The fineness of the blended cements produced were determined using air permeability method (Blaine method) as specified in BS EN 196-5: 1995. The equipment used was the weighing balance and the blaine permeability.

Residue on $45 \mu \mathrm{m}$ sieve: - The residue on $45 \mu \mathrm{m}$ sieve was determined as specified in BS EN 196-5: 1995. The equipments used were weighing balance, $45 \mu \mathrm{m}$ Sieve and sieving machine.

Initial and final setting times: - For the determination of the initial setting time, a round needle with a diameter of $1.13 \pm 0.05 \mathrm{~mm}$ was used. A similar needle fitted with a metal attachment $5 \mathrm{~mm}$ in diameter was used to determined final setting time.

Heat of hydration:- Heat of hydration of the blended cement was determined by heat of solution method using vacuum flask calorimeter fitted with a Beckmann thermometer as specified in ASTM C 186-82: 1995. Mixture of dry cement, nitric and hydrofluoric acid was placed inside the flask and the temperature rise was measured in degree Celsius on the thermometer after six (6) hours.

Also the chemical characteristics of each of the blended cements were determined using X-ray fluorescence analyser (Model: QX 1279) as specified in BS EN 196-2: 1995 adopted. The chemical compositions that were determined are silica $\left(\mathrm{SiO}_{2}\right)$, aluminum oxide $\left(\mathrm{Al}_{2} \mathrm{O}_{3}\right)$, ferric oxide $\left(\mathrm{Fe}_{2} \mathrm{O}_{3}\right)$, calcium oxide $(\mathrm{CaO})$, magnesium oxide $(\mathrm{MgO})$, sulphur trioxide $\left(\mathrm{SO}_{3}\right)$, sodium oxide $\left(\mathrm{Na}_{2} \mathrm{O}\right)$, potassium Oxide $\left(\mathrm{K}_{2} \mathrm{O}\right)$ and phosphorus oxide $\left(\mathrm{P}_{2} \mathrm{O}_{5}\right)$. Also loss on ignition (LOI), free lime and insoluble residue (IR) were also determined.

\section{Results and Discussion}

\section{Chemical composition of softwood ashes and clinker}

Table 2 shows the mean value of elemental oxides present in the AOA, sample by using X-ray fluorescence analyser (Model: QX1279) as specified in BSEN 196-2:1995. The results indicate that the samples of ash from AOA had total percentage of silica $\left(\mathrm{SiO}_{2}\right)$, Alumina $\left(\mathrm{Al}_{2} \mathrm{O}_{3}\right)$ and Ferric oxides of 70.50 . This value was higher than the value (61.18) reported by Raheem and Adenuga (2013) in which the type of wood that produces the ash was not known. This indicates that the ash is a good pozzolanic material in accordance with ASTM C 618, 2001 a requirements which a good pozolan for manufacture of blended cements should meet.

Table 2: Percentage composition of softwood ash

\begin{tabular}{|c|c|c|c|c|}
\hline $\begin{array}{l}\text { Chemical } \\
\text { constituents }\end{array}$ & $\begin{array}{l}\text { Percontage } \\
\text { Compositions }(\%) \\
\text { AOA } 1\end{array}$ & $\mathrm{AOA} 2$ & $\mathrm{AOA} 3$ & Averase \\
\hline $\mathrm{SiO}_{2}$ & 62.05 & 62.10 & 62.00 & $62.0 \overline{5}$ \\
\hline $\mathrm{Al}_{2} \mathrm{O}_{3}$ & 5.55 & 5.57 & 5.56 & $5 . \overline{5}$ \\
\hline $\mathrm{Fe}_{2} \mathrm{O}_{3}$ & 2.90 & 2.89 & 2.88 & 2.89 \\
\hline $\mathrm{CaO}$ & 10.00 & 10.00 & 10.00 & 10.00 \\
\hline $\mathrm{MgO}$ & 3.60 & 3.59 & 3.61 & 3.60 \\
\hline $\mathrm{SO}_{3}$ & 1.45 & 1.44 & 1.46 & $1.4 \bar{\jmath}$ \\
\hline $\mathrm{K}_{2} \mathrm{O}$ & 5.79 & 5.76 & 5.76 & 5.77 \\
\hline $\mathrm{Na}_{2} \mathrm{O}$ & 0.35 & 0.36 & 0.54 & 0.35 \\
\hline Total $\mathrm{SiO} 2+\mathrm{Al}_{2} \mathrm{O}_{3}+\mathrm{Fe}_{2} \mathrm{O}_{3}$ & 70.40 & 70.56 & 70.44 & $70 . \overline{30}$ \\
\hline
\end{tabular}

Table 3 shows the chemical composition of the clinker used. The values obtained for the elemental oxide are in agreement with range of values reported by Adesanya and Raheem (2009). The composition also satisfied the requirement in ASTM C150:1994 and NIS 439:2000. Thus the clinker is quite suitable for cement production. 
Table 3 Chemical composition of clinker used

\begin{tabular}{lllll}
\hline $\begin{array}{l}\text { Chemical } \\
\text { Composition }\end{array}$ & $\begin{array}{l}\text { Percentage } \\
\text { Composition(\%) } \\
\text { Sample 1 }\end{array}$ & Sample 2 & Sample 3 & Average \\
\hline $\mathrm{SiO}_{2}$ & 20.22 & 20.25 & 20.45 & 20.30 \\
$\mathrm{Al}_{2} \mathrm{O}_{3}$ & 5.30 & 5.45 & 5.65 & 5.47 \\
$\mathrm{Fe}_{2} \mathrm{O}_{3}$ & 3.43 & 3.26 & 3.72 & 3.47 \\
$\mathrm{CaO}$ & 66.00 & 64.85 & 66.85 & 65.90 \\
$\mathrm{MgO}$ & 2.28 & 1.98 & 1.80 & 2.02 \\
$\mathrm{SO}$ & 2.14 & 2.14 & 2.23 & 2.17 \\
$\mathrm{Na}_{2} \mathrm{O}$ & 0.15 & 0.15 & 0.15 & 0.15 \\
$\mathrm{~K} \mathrm{O}$ & 0.29 & 0.32 & 0.23 & 0.28 \\
$\mathrm{P} 2$ & 0.17 & 0.13 & 0.21 & 0.17 \\
$\mathrm{LOI}$ & 1.33 & 1.30 & 1.30 & 1.31 \\
$\mathrm{LSF}$ & 95.93 & 95.73 & 96.04 & 95.90 \\
$\mathrm{AR}$ & 1.55 & 1.64 & 1.45 & 1.55 \\
$\mathrm{SR}$ & 2.23 & 2.35 & 2.17 & 2.25 \\
Free lime & 1.11 & 1.05 & 0.94 & 1.03 \\
\hline
\end{tabular}

\section{Chemical composition of AOA blended cements}

The chemical composition of AOA blended cements produced by using the ash and clinker presented in Table 2 and 3 above are presented in Table 4 . The silica content of the blended cements increased from $20.08 \%$ for $5 \%$ replacement to $21.15 \%$ for $50 \%$ replacement. This is in line with the findings of Adesanya and Raheem (2009) that reported increase in Silica contents of corn cob ash (CCA) blended cement as the percentage of CCA increases and also in line with Raheem and Kareem (2017) that reported increase in Silica contents of rice husk ash (RHA) blended cement as the percentage of RHA increases. AOA blended cements satisfied the minimum of $20 \%$ silica content requirements for Type II and Type IIA Portland Cement as specified by ASTM C150: 1994.

Table 4 Chemical composition of AOA-blended cement

\begin{tabular}{llllllllllll}
\hline \multicolumn{1}{c}{ Oxide } & \multicolumn{1}{c}{ Percentage composition (\%) } \\
\cline { 2 - 11 } & $0 \%$ & $5 \%$ & $10 \%$ & $15 \%$ & $20 \%$ & $25 \%$ & $30 \%$ & $35 \%$ & $40 \%$ & $45 \%$ & $50 \%$ \\
\hline $\mathrm{SiO}_{2}$ & 20.15 & 20.08 & 20.16 & 20.18 & 20.22 & 20.24 & 20.40 & 20.62 & 20.80 & 20.90 & 21.15 \\
$\mathrm{Al}_{2} \mathrm{O}_{3}$ & 4.96 & 4.92 & 4.90 & 4.86 & 4.84 & 2.80 & 4.78 & 4.72 & 4.66 & 4.64 & 4.50 \\
$\mathrm{Fe}_{2} \mathrm{O}_{3}$ & 2.89 & 2.88 & 2.86 & 2.82 & 2.78 & 2.76 & 2.72 & 2.68 & 2.64 & 2.60 & 2.58 \\
$\mathrm{CaO}$ & 63.66 & 63.62 & 63.52 & 63.44 & 63.20 & 63.00 & 62.68 & 62.44 & 61.98 & 61.50 & 61.00 \\
$\mathrm{MgO}$ & 1.78 & 1.80 & 1.84 & 1.88 & 1.92 & 1.96 & 2.00 & 2.20 & 2.30 & 2.40 & 2.48 \\
$\mathrm{SO}_{3}$ & 2.26 & 2.28 & 2.32 & 2.36 & 2.38 & 2.42 & 2.46 & 2.48 & 2.52 & 2.56 & 2.58 \\
$\mathrm{~K}_{2} \mathrm{O}$ & 0.21 & 0.22 & 0.24 & 0.26 & 0.30 & 0.34 & 0.38 & 0,42 & 0.50 & 0.60 & 0.90 \\
$\mathrm{Na}_{2} \mathrm{O}$ & 0.03 & 0.02 & 0.02 & 0.02 & 0.01 & 0.01 & 0.01 & 0.00 & 0.00 & 0.00 & 0.00 \\
$\mathrm{Na}_{2} \mathrm{O}$ & 0.00 & 0.01 & 0.01 & 0.01 & 0.02 & 0.02 & 0.03 & 0.03 & 0.09 & 0.10 & 1.14 \\
$\mathrm{Free} \mathrm{Lime}$ & 2.10 & 1.91 & 1.89 & 1.82 & 1.72 & 1.70 & 1.67 & 1.65 & 1.58 & 1.54 & 1.46 \\
$\mathrm{LSF}$ & 0.99 & 0.99 & 0.99 & 0.99 & 0.98 & 0.98 & 0.97 & 0.96 & 0.95 & 0.93 & 0.92 \\
$\mathrm{SR}$ & 2.56 & 2.57 & 2.59 & 2.62 & 2.65 & 2.68 & 2.72 & 2.78 & 2.85 & 2.88 & 2.88 \\
$\mathrm{AR}$ & 1.71 & 1.70 & 1.71 & 1.72 & 1.74 & 1.74 & 1.76 & 1.76 & 1.77 & 1.78 & 1.74 \\
$\mathrm{C}_{3} \mathrm{~S}$ & 67.66 & 67.60 & 67.40 & 67.20 & 66.88 & 66.40 & 66.10 & 65.80 & 65.30 & 64.00 & 62.00 \\
$\mathrm{C}_{3} \mathrm{~A}$ & 8.26 & 8.20 & 8.16 & 8.00 & 7.88 & 7.86 & 7.82 & 7.80 & 7.76 & 7.70 & 7.20 \\
$\mathrm{C}_{4} \mathrm{AF}$ & 8.80 & 8.84 & 8.82 & 8.78 & 8.74 & 8.60 & 8.65 & 8.60 & 8.56 & 8.52 & 8.00 \\
\hline
\end{tabular}

As the percentage of AOA increased, there was a decrease in the contents of alumina and ferric oxide of AOA blended cements. Alumia contents decreased from 4.92 to 4.50 and ferric oxide decreased from 2.88 to 2.58 for $5 \%$ to $50 \%$ replacement, respectively. However, all the blended cements satisfied the maximum of $6.00 \%$ alumina content requirements for Type II and Type IIA Portland cement specified by ASTM C150-02.

Calcium oxide $(\mathrm{CaO})$ and lime saturated factor (LSF) follow similar trend with alumina and ferric oxides. $\mathrm{CaO}$ contents of AOA blended cements decreased from 63.62 to 61.00 as the percentage of $\mathrm{AOA}$ was increased from $5 \%$ 
to $50 \%$ replacement. The LSF decreased from 0.99 to 0.92 for $5 \%$ to $50 \%$ replacement, this means that addition of AOA reduces the lime content of the AOA blended cements. This is in line with the findings of Adesanya and Raheem (2009) and Raheem and Kareem (2017). $\mathrm{CaO}$ and $\mathrm{SiO}_{2}$ are responsible for the formation of tricalcium silicate $\left(\mathrm{C}_{3} \mathrm{~S}\right.$ or $\left.3 \mathrm{CaO} . \mathrm{SiO}_{2}\right)$ and Dicalcium silicate $\left(\mathrm{C}_{2} \mathrm{~S}\right.$ or $\left.2 \mathrm{CaO}_{2} \mathrm{SiO}_{2}\right)$ in cement and all other clinker minerals. These two compounds are responsible for the strength in the late or early part of the concrete (Taylor, 2004).

The minor oxide compounds of $\mathrm{Na}_{2} \mathrm{O}$ and $\mathrm{K}_{2} \mathrm{O}$ known as alkalis for $\mathrm{AOA}$ blended cements ranged from $0.02 \%$ $0.00 \%$ and $0.22 \%-0.90 \%$, for $5 \%$ to $50 \%$ replacement, respectively. These values are higher than those of the control which are $0.03 \%$ for $\mathrm{Na}_{2} \mathrm{O}$ and $0.21 \% \mathrm{~K}_{2} \mathrm{O}$. These amount of alkalis are lower compared to Adesanya and Raheem (2009) and Raheem and Kareem (2017). Higher alkalis in cement are undesirable as it causes damage to kiln and attack reinforced concrete as reported by Taylor (2004). It also results in alkali -silicates reaction (Dabai et $a l ., 2009$ ). The loss on ignition (LOI) of the AOA-blended cements was higher than that of the control and ranges from $1.45 \%$ to $2.90 \%$ as against the $1.28 \%$ for the control. According to Adesanya and Raheem (2009) the higher the LOI, the higher the organic content of the cement which will result to lower binding power of the cement. However, all the value of LOI of AOA blended cements are lower than the recommended limit of $5 \%$ by NIS 439:2000 requirements. This means that AOA blended cement have lower organic content and good binding power.

\section{Physical properties of AOA blended cements}

Table 5 shows the results of fineness and residue on $45 \mu \mathrm{m}$ sieve of AOA blended cements. The fineness of AOA blended cements ranges from $353 \mathrm{~m}^{2} / \mathrm{kg}$ for $5 \%$ to $535 \mathrm{~m}^{2} / \mathrm{kg}$ for

$50 \%$. As the percentage of AOA is increased, the fineness of AOA blended cement also increases because AOA is of lower density compared to OPC-clinker and gypsum. AOA blended cements produced satisfied the $250 \mathrm{~m}^{2} / \mathrm{kg}$ and $280 \mathrm{~m}^{2} / \mathrm{kg}$ minimum fineness specified by NIS 439:2000 and ASTM C 150:2000, respectively. The AOA blended cements residue on $45 \mu \mathrm{m}$ sieve increases from $19.10 \%$ to $29.00 \%$ for $5 \%$ to $50 \%$, replacement as AOA is increased. The coarseness was attributed to the clinker component which was harder to grind compared with the pozzolan. Hence, it could be concluded that the relative hardness of the pozzolan significatly influences the increase in the setting time of the produced cements.

Table 5: Physical characteristics of AOA blended cements

\begin{tabular}{lll}
\hline $\begin{array}{l}\text { Percentage replacement of AOA } \\
(\%)\end{array}$ & $\begin{array}{c}\text { Fineness } \\
\left(\mathrm{m}^{2} / \mathrm{kg}\right)\end{array}$ & $\begin{array}{c}\text { Residue on } 45 \mu \mathrm{m} \text { sieve } \\
(\%)\end{array}$ \\
\hline 0 & 352 & 13.40 \\
5 & 353 & 19.10 \\
10 & 355 & 19.70 \\
15 & 379 & 20.00 \\
20 & 410 & 20.50 \\
25 & 420 & 21.50 \\
30 & 469 & 22.75 \\
35 & 500 & 23.75 \\
40 & 515 & 25.55 \\
45 & 520 & 27.00 \\
50 & 535 & 29.00 \\
\hline
\end{tabular}

The initial and final setting time for AOA blended cements is shown in Figure 1. The initial and final setting time increased from $50 \mathrm{~min}$ to $135 \mathrm{~min}$ and $75 \mathrm{~min}$ to $265 \mathrm{~min}$, respectively as the percentage of AOA replacement increases from $5 \%$ to $50 \%$. AOA blended cements satisfy the NIS 439:2000 requirement of 45 min minimum initial setting time and maximum of $10 \mathrm{hrs}$ final setting time. The variation increase in setting time as percentage replacement of AOA increased lead to slowing down of hydration process. The slow hydration is an indication of low rate of heat development, which is one of the notable characteristics for which pozzolan cement are known and is of great importance in mass concrete construction where low rate of heat development is very essential as it reduces thermal stresses. 


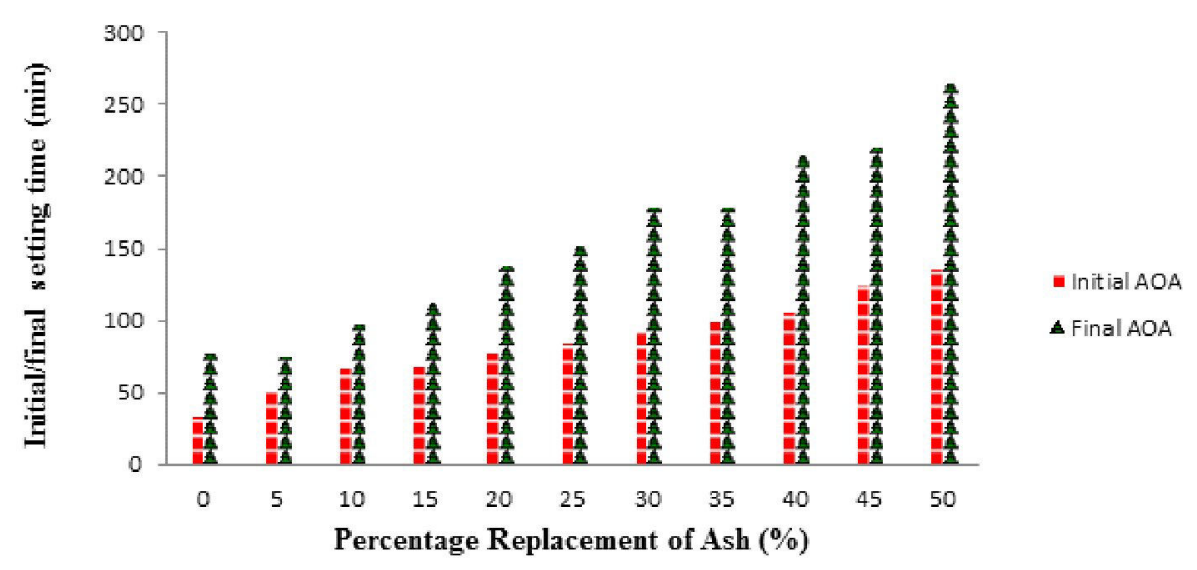

Fig 1. Effects of initial and final setting time on AOA blended cements

Figure 2 show the variation of heat of hydration of AOA blended cement with different percentage replacement ash for duration of six hours. It was revealed that the temperature of the control sample increases consistently while all AOA replacements levels were constant for some hours before showing slight changes in temperature. This means that, the control sample generated more heat of hydration at early stage while AOA blended cements produced low heat of hydration at early stage. It can also be seen that as the percentage replacement of AOA increases, the heat of hydration of all the wood ash blended cements reduces.

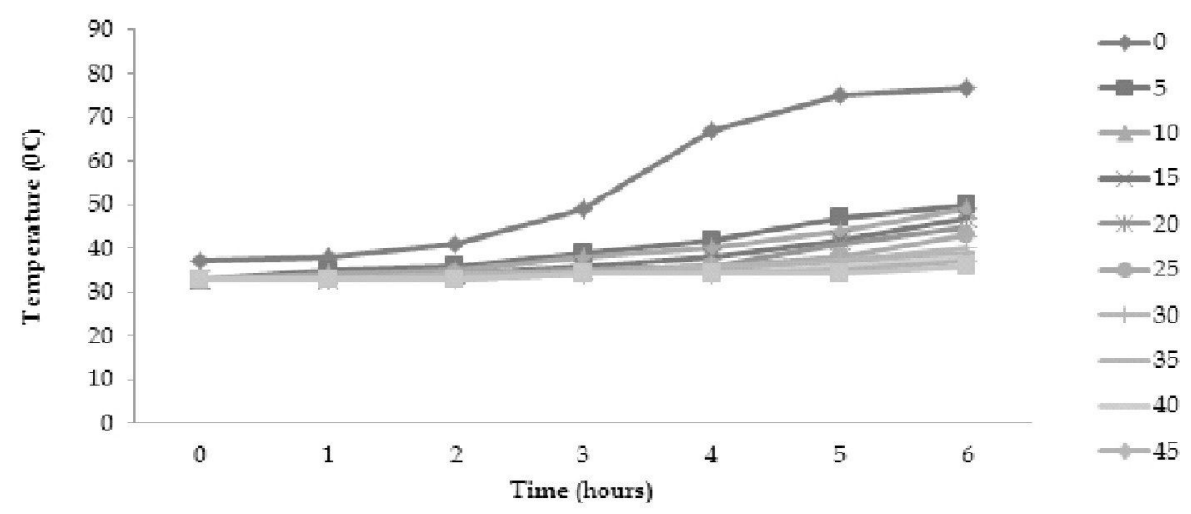

Fig. 2: Heat of hydration of AOA blended cements

\section{Conclusion}

The following conclusion re draw from the study:

i. AOA is a suitable material for use as a pozzolan, since it satisfied the requirement for such a material by having the sum of $\mathrm{SiO}_{2}, \mathrm{Al}_{2} \mathrm{O}_{3}$ and $\mathrm{Fe}_{2} \mathrm{O}_{3}$ of more than $70 \%$.

ii. The addition of $A O A$ as pozzolan in blended cement increases marginally the oxide composition of $\mathrm{SiO}_{2}$ and decrease slightly that of $\mathrm{Al}_{2} \mathrm{O}_{3}, \mathrm{Fe}_{2} \mathrm{O}_{3}$ and $\mathrm{CaO}$.

iii. AOA blended cement satisfied BS 12:1991, ASTM C 150:1994 and NIS 439:2000 requirement for up 20\% replacement of ash.

iv. As AOA blended cement have higher setting time than the control hence, they are most applicable where low rate of heat development is required. This shows that all the blended cement are good as low heat cement.

AOA blended cements is recommended for use where low heat cement is applicable such as dam construction.

\section{Acknowledgements}

The authors acknowledge the management of West African Portland Cement Company (WAPCO) Sagamu Works, Ogun State, Nigeria; for the opportunity given to perform various laboratory tests using their materials and facilities. 


\section{References}

Abdullahi, M. (2006). Characteristics of Wood Ash/OPC concrete. Leonardo Electronic of Practices and Technologies, 8:9-16.

Adama, Y.A, and Jimoh, Y.A. (2011). Production and Classification of Locust Bean Pod Ash (LBPA) as a Pozzolan. Available at www.engineeringcivil.com Retrieved 29 January, 2012.

Adesanya, D. A. and Raheem, A. A. (2009) Development of corn cob ash blended cement. Journal of Construction and Building Materials, 23:347-352

Adesanya, D. A. and Raheem, A. A. (2010) A Study of the Permeability and acid attack of Corn Cob Ash Blended Cement Concrete. Construction and Building Materials Journal, 24:403-409.

American Society for Testing and Materials. Specification for Portland Cement. ASTM C 150, 1994

ASTM C 150, (2002). Standard Specification for Portland Cement. Annual book of ASTM Standards (Revised Edition). $4(2): 1-7$.

American Society for Testing and Materials. Standard Specification for Coal Fly Ash and Raw Calcined Natural Pozzolan for use as a Mineral Admixture in Concrete. ASTM C 618, 2001.

American Society for Testing and Materials. Standard Method for Compressive Strength of Hydraulic Cement Mortars. ASTMC186/82M, 1995.

Arthanari, S.; Augustine, A. G.; Dayanithi, P.; Ramaswamy, S.; Sethurathnam, A., and Thanikachalam,V. (1981). Building Technology and Valuation, TataMc.Graw-hill, New Delhi,

Bristish Standard Institution. Specification for Portland Cements, BS 12, London, Bristish Standard Institution, 1991.

BS EN 196-2 (1995). Method of testing Cement - 2: Chemical analysis of Cement. British Standard Institute, 389 Chiswick high Road, London, W44AL.

BS EN 196-5 (1995). Method of testing Cement - 5: Pozzolanicity Test for Pozzolanic Cements. British Standard Institute, 389 Chiswick high Road, London, W44AL.

Cement Association of Canada, (2001). Background History and early uses of Portland Cement, Ottawaa, Ontario, Canada.

CheahChee, B. and Mahudin, R. (2011) Properties of high calcium wood ash and densified silica fume blended cement, International Journal of Physical Sciences, 6(28): 6596-6606.

Chungsangunsit, T., Gheewla, H. and Patumsawad, S. (2009). Emission Assessment of Rice Husk Combustion for Power Production. World Academy of Science, Engineering and Technology Journal, 53: 1070 - 1075.

Coutinho, J.S. (2003). The Combined Benefits of CPF and RHA in Improving the Durability of Concrete Structures. Cement and Concrete Composites. 25:51-59.

Dabai, M., Muhammad, C., Bagudo, B. and Musa, A. (2009). Study on the effect of Rice Husk Ash as Cement Admixture. Nigeria Journals of Basic and Applied Sciences .

Dwivedi, V.N., Singh, N.P., Das, S.S. and Singh N.B. (2006). A new pozzolanic material for the cement industry: bambooleaf ash. International Journal of Physical Sciences, 1 (3): 106 - 111.

Etiegni. L., Campbell. A. G. (1991). Physical and chemical characteristics of wood ash. Bio -resource Technology, $37(2): 173-178$.

NIS 439 (2000). Stardard Organisation of Nigeria. Standard for Cement. Lagos Nigeria.

Marthong. C. (2012). Sawdust Ash (SDA) as Partial Replacement of Cement, Int. J. Engg. Res. App., 2 (4): $1980-1985$.

Olonode, K.A. (2010). Prospect of Agro-By-Products asPozzolans in Concrete for Low-Cost Housing Delivery in Nigeria. Proceedings of the International Conference of the ObafemiAwolowo University, Faculty of Technology, 1: 217-221.

Raheem, A.A., Osika, E.M. and Adedokun A.M. (2012). Corn Husk Ash as a Partial Replacement for Ordinary Portland cement in Concrete. Journal of Engineering Research, 17 (1):56- 63.

Raheem, A.A. and Adenuga, O.A (2013). Wood Ash from Bread Bakery as Partial Replacement for Cement in Concrete. International Journal of Sustainable Construction Engineering E Technology (ISSN: 2180-3242), $4(1)$ : 75 -81 .

Raheem, A.A. and Kareeem, M.A. (2017). Chemical Composition and Physical Characteristics of Ricehusk Ash Blended Cements. International Journal of Engineering in Africa. ISSN: 1663-4144, pp 25-35, DOI:10.4028/www.scientific.net/JERA.32.25

Raheem, A. A. and Orogbade, B. O. (2018). Characteristics of Blended Cements from Selected Hardwood Ashes, FUOYE Journal of Engineering and Technology (FUOYEJET), Vol3, Iss 1

Salau, M.A., Ikponmwosa, E.E., and Olonode, K.A. (2012). Structural Strength Characteristics of Cement Cassava Peel Ash Blended Concrete. Journal of Civil and Environmental Research. IISTE 2 (10). Available at 